\title{
EDITORIAL
}

\section{GEOUSP - a história de um projeto}

Em 1944 é defendida, no
Departamento de Geografia da Universidade da São Paulo, a primeira tese de doutorado na área de Geografia Humana realizada no Brasil, de lá até hoje foram defendidas outras 438.

Ao longo do tempo, a capacidade da produção de um conhecimento geográfico sobre a realidade brasileira, foi em muito, superior a possibilidade de sua divulgação, esse descompasso entre produção e veiculação das idéias produzidas esta na base da concepção desta revista.

No ano de 1996 insistia na necessidade de criação de uma revista que desse visibilidade a produção geográfica realizada no âmbito da pós-graduação, afinal, nossos alunos vinham de todas as partes do Brasil, eram, em muitos casos, professores de universidades brasileiras, com uma boa formação, o que garantia a pesquisa bem fundamentada enfocando as mais variadas regiões brasileiras. Havia, portanto, no DG, um volume de pesquisa não negligenciavel revelando uma contribuição significativa à construção do pensamento geográfico brasileiro. Uma produção sempre renovada apontando questões, bem como, novos caminhos para a pesquisa. Neste processo, a construção de uma análise da realidade brasileira enquanto movimento ininterrupto. É a partir da pesquisa que se gesta um pensamento capaz de explicitar a realiidade brasileira, de levantar questões para - debate sobre os caminhos, e as perspectivas que se abrem para a análise geográfica e de uma Geografia que se recria, incessantemente, em função do momento constitutivo da realidade.

Em 1996 a então coordenadora do programa de geografia Humana, professora Ana Maria Marangoni me informa da existência de verba para meu antigo projeto de uma revista da pósgraduação. Estava lançada a possibilidade de concretização do projeto, transformando-se aos poucos num trabalho coletivo, engajando uma parte significativa de professores do DG.

Ao longo destes anos, a revista passou por vários momentos ganhando novas feições e objetivos. As mudanças, necessárias ao desenvolvimento da revista, vão se constituindo num movimento ininterrupto de renovações como condição de sua própria existência. Se ela surge, com o objetivo precípuo de dar visibilidade a produção realizada pelos alunos de pós- graduação, ao completar 2 anos, a revista, abre suas páginas para todos os envolvidos na produção do conhecimento geográfico no Brasil e não só os alunos do programa de Pósgraduação, deste Departamento. Uma nova sessão "Intercâmbio" se abre à publicação de artigos produzidos por professores estrangeiros com os quais os professores deste Departamento mantém relações de pesquisa e intercâmbio acadêmico (número 4). O número 6 traz a mudança mais importante, a GEOUSP que estava voltada apenas para a produção geográfica realizada na área de geografia humana, incorpora a produção da geografia física. A última novidade (número 10) não se encontra nas páginas 
da revista, mas na tela do computador; a GEOUSP conta com uma versão eletrônica.

Em sintese podemos afirmar que a GEOUSP vai revelar a idéia que esta na base do currículo da geografia do Departamento, que é a possibilidade do exercicio do diferente o que significa que não há uma hegemonia teórico metodológica; e respeita-se, sobretudo o direito à diferença, o que cria a multiplicidade de abordagens temática e metodológica quanto ao modo como a pesquisa geográfica se realiza. Aí reside a nossa liberdade, enquanto exercício da diferença, comportamento que abre sempre novas perspectivas e que dá movimento a reprodução do conhecimento, que foi consolidada ao longo da história do departamento. Nasce com um compromisso de veiculação do conhecimento crítico, produzido enquanto exercício de liberdade capaz de contemplar a pluralidade do pensamento e dos caminhos abertos à pesquisa e como elemento propulsor do debate. Seu objetivo é aquele de abrir espaço para a divulgação da reflexão produzida a partir dos trabalhos de pesquisa, comprometidos com o desvendamento da realidade brasileira a partir ou através da Geografia. Mas uma revista significa, antes de mais nada, a possibilidade do intercâmbio de idéias, sem as quais o conhecimento não avança - por isso a estratégia da Internet.

Sobre o seu conteúdo podemos afirmar abrange um amplo leque, revelando a geografia que se faz no Brasil - num debate acirrado que repõe constantemente a relação homem/ natureza no centro do debate acadêmico. No entanto que se revela é a construção de um pensamento geográfico que se vai realizando na emergência ou possi- bilidades da análise dos lugares revelados em estudos profundos, no debate das análises emergentes da realidade brasileira preocupada com a revelação do mundo, no desvendamento das contradições que emergem do processo de reprodução do espaço, enfim que é a partir do trabalho de pesquisa que a geografia vai ganhando novos contornos e matizes. Dar visibilidade a essas pesquisas na forma de artigos ou notas de pesquisa - é o objetivo procípuo desta revista.

Por outro lado, convém destacar que o contexto em que se realiza a pesquisa geográfica brasileira desvenda o processo de desenvolvimento do capitalismo num país periférico; portanto, nas páginas da GEOUSP o que se revela é o processo de desenvolvimento desigual e contraditório com o qual convivemos. É assim que os temas vão ganhando forma e revelando a realidade brasileira, onde o modo como o capitalismo se reproduz dá o contorno de nossas crises propondo transformações profundas na relação sociedade/natureza, redefinindo-a. Aqui a profunda desigualdade de renda que constrange, delimita a vida e vai produzindo estratégias de sobrevivência revelando o sentido das lutas que se desenvolvem no território brasileiro como um todo analisadas a partir de estudos aprofundados, apoiados em fragmentos da realidade brasileira apontando um cenário de profundas desigualdades sociais, de pobreza, de sempre renovadas estratégias de sobrevivência criadas tanto na cidade, quanto no campo. O modo como se dá o acesso à propriedade privada da terra, por exemplo, posta como condição do processo de reprodução do espaço brasileiro, repõe com força os debates em 
torno da reforma agrária e dos movimentos que surgem tanto no campo brasileiro (o MST- que ganha cada vez mais importância no cenário brasileiro), quanto nas cidades. No cerne do processo de construção continuada do território o modo como o "moderno" penetra no campo modificando a produção aumentam o desnível entre a agricultura de exportação e a lavoura tradicional, bem como o modo como se criam, nas cidades, novas atividades econômicas visando a realização do capital.

O desvendamento da realidade brasileira, repõe, portanto, o debate sobre os caminhos da construção do pensamento geográfico.

\section{As sessões da GEOUSP}

A primeira apresenta artigos que recebemos de todo o país, apontam para temas e contribuições os mais diversas, dando conta da diversidade da geografia brasileira dividida, na realidade da pesquisa, entre geografia física e geografia humana.

\section{As notas de pesquisa de campo} como sessão permanente - revelam a especificidade da geografia: esta na origem da tradição geográfica a observação da terra onde o trabalho de campo aponta um modo de fazer, de coletar dados primários, de contato com a realidade, de exposição de uma metodologia. É parte indissociável do processo de investigação que longe de "comprovar" teorias, coloca o pesquisador diante de fontes primárias, fazem-no ver, conviver, e sentir pessoas e lugares.

As resenhas, sessão necessária em qualquer revista, traz, preferencialmente, a produção da geografia brasileira. O intercâmbio revela nossas redes. Já os editoriais apontam um pouco das transformações que os cursos de pósgraduação vem sofrendo no Brasil, lidos através da relação com a CAPES - uma instituição de fomento a pesquisa no Brasil, revelando as mudanças por que passa a universidade brasileira no seu caminho rumo ao modelo neoliberal.

Neste número mais uma mudança significativa a número 12 traz duas versões - em português no formato de costume em papel em dos intercâmbios mantidos com bibliotecas do Brasil e do exterior e versão português / inglês na sua forma eletrônica no site www.geografia.fflch.usp.br

Enfim a GEOUSP pretende expor em suas páginas um debate que crie a possibilidade de juntos criarmos as bases de construção de um pensamento geográfico, crítico capaz de proporcionar um entendimento do mundo a partir da Geografia realizada enquanto exercício da crítica. $\mathrm{E}$ isso depende de todos nós.

\footnotetext{
1. Professora Livre Docente do Departamento de Geografia da Faculdade de Filosofia, Letras e Ciências Humanas da Universıdade de São Paulo, Brasil e coordenadora da GEOUSP juntamente com o prof. Jurandyr Ross.
} 